ACTA MYCOLOGICA

Vol. 48 (1): 33-39

2013

DOI: $10.5586 / \mathrm{am} .2013 .005$

\title{
Changes of hypogeous funga in the Carpathian-Pannonian region in the past centuries
}

\author{
ZOLTÁN BRATEK, ZSOLT MERÉNYI and TORDA VARGA \\ Department of Plant Physiology and Molecular Plant Biology, Eötvös Loránd University \\ Pázmány sétány 1/C, H-1117 Budapest, bratek@caesar.elte.hu
}

Bratek Z., Merényi Zs., Varga T.: Changes of hypogeous funga in the Carpathian-Pannonian region in the past centuries. Acta Mycol. 48 (1): 33-39, 2013.

The exploration of hypogeous fungi in the Carpathian-Pannonian region speeded up in the past decades, owing to the widespread of truffle hunting with dogs. As a result, not only several new species were found in the region, but our view of the frequency of truffles also changed fundamentally. It became evident that Tuber aestivum, T. brumale, T. macrosporum, T. magnatum, T. mesentericum and Mattirolomyces terfezioides can be collected in commercial quantity. Among the dog preferred hypogeous fungi (DPH) several species, earlier believed to be rare like Octaviania asterosperma and Stephensia bombycina, also occurred. The taxonomic alterations and revisions brought about changes in the list of hypogeous fungi, and further changes are expected from molecular taxonomy research on a number of genera at present.

Key words: list of underground fungi, mycota, distribution, dog preferred hypogeous fungi, Hungary

\section{INTRODUCTION}

There are only few publications which have focused on the distribution of hypogeous fungi in European regions (Lawrynowicz 1989, 1990, 1992; Montecchi, Sarasini, 2000; Riousset et al. 2001). The Carpathian-Pannonian region is considered as one of the best known biogeographical regions of the hypogeous funga. This is partly because a number of manuscripts have reported and described hypogeous fungi since the $16^{\text {th }}$ century, but mainly because two world-famous researchers, László Hollós (1911) and László Szemere (1965) made a detailed inventory of hypogeous fungi in the past nearly 200 years in their books. During his work Hollós published roughly 460 data of 52 hypogeous fungi in the Carpathian Basin. Szemere (1970) reported on 86 species in his book. Such richness of the hypogeous funga may be attributed to the varied landscape, the superposition of several climatic effects and the diversity of 
soil types in the Carpathian-Pannonian biogeographic region (Stanners, Bourdeau 1995).

Following the hardships of the last century, at the end of it, truffle hunting with dogs became popular in a number of countries in the region. The mapping and preservation of hypogeous fungi in fungaria also progressed by the leadership of professional organisations and societies. Collections in the past decades did not only reveal species new to the region, but modified our knowledge on the frequency of occurrence and ecological requirements of some species. Although the practice of using dogs for collection produced a large amount of data, it was evident that species with the most preferable odour were overrepresented. As collection for commercial purposes became general, collectors started to focus on certain forest types or landscapes, and dog owners often discouraged their dogs from finding non-commercial species. Consequently, data from dog-aided collections can be considered representative only for species of commercial importance and their accompanying species. It is worth mentioning that these very data could have laid the foundations of the legal regulations for truffle collecting. The assessment of the distribution of other hypogeous species raises further questions in terms of sampling and collecting.

Being aware of the above mentioned diverse collecting methods and aims, in this paper we aim at reassessing the frequency of occurrence of hypogeous fungal species in the region and unrevealing the likely causes of changes and the possibilities of utilization and protection.

\section{MATERIALS AND METHODS}

In cooperation with collectors of the First Hungarian Truffle Society (EMSzE), we compiled a fungarium of 4224 preserved specimens of hypogeous fungi in the past three decades. Data on collection and available habitat descriptions were organised in a database (Merényi et al. 2010). Present study compares the occurrence data of species in the database with the published data of Hollós (1911) and Szemere (1970).

\section{RESULTS AND DISCUSSION}

Table 1 shows the species used for comparison. Some taxa in Table 1 appear with genus names only as their classification at species level is still unclear, and they are under molecular taxonomic investigations. For simplicity, species will be discussed in three large groups.

Taxonomic changes and revisions. Following the publication of Szemere's book (1970), many researchers revised his fungarium. A detailed evaluation of these revisions is given by Bratek and Halász (2005). The following species were removed from Szemere's list by the revisions: Choiromyces magnusii (Matt.) Paoletti and Endogone irregularis Szem. New species on his list are: Glomus caledonium (Nicol. et Gerd.) Gerd. et Trappe, Glomus fasciculatum (Thaxt.) Gerd. et Trappe and Hymenogaster remyi Dodge et Zeller. All Rhizopogon species were merged into Rhizopogon roseolus 
Table 1

The occurrence data of taxons found in the Carpathian-Pannonian region based on the published data of Hollós (1911), Szemere (1970) and on the actual database of First Hungarian Truffle Society (EMSzE)

\begin{tabular}{|c|c|c|c|}
\hline Species & $\begin{array}{l}\text { Hollós } \\
\text { (1911) }\end{array}$ & $\begin{array}{c}\text { Szemere } \\
(1970)\end{array}$ & $\begin{array}{c}\text { EMSZzE } \\
(2013)\end{array}$ \\
\hline \multicolumn{4}{|l|}{ Ascomycota } \\
\hline Elaphomyces aculeatus Vittad. & 8 & 2 & 26 \\
\hline Elaphomyces anthracinus Vittad. & 5 & 3 & 2 \\
\hline Elaphomyces asperulus Vittad. & 11 & 1 & 7 \\
\hline Elaphomyces decipiens Vittad. & - & - & 6 \\
\hline Elaphomyces granulatus $\mathrm{Fr}$. & 9 & - & 31 \\
\hline Elaphomyces leveillei Tul. & 1 & - & 2 \\
\hline Elaphomyces maculatus Vittad. & 1 & 16 & 3 \\
\hline Elaphomyces muricatus Fr. & 28 & 1 & 146 \\
\hline Elaphomyces persoonii Vittad. & - & - & 4 \\
\hline Elaphomyces reticulatus Vittad. & - & - & 10 \\
\hline Elaphomyces virgatosporus Holl. & - & - & 11 \\
\hline Balsamia platyspora $\mathrm{Bk}$. & - & - & 2 \\
\hline Balsamia polysperma Vittad. & 12 & - & 13 \\
\hline Balsamia vulgaris Vittad. & - & 9 & 18 \\
\hline Balsamia sp. (undet.) & - & - & 32 \\
\hline Hydnotrya cerebriformis Harkn. & - & - & 2 \\
\hline Hydnotrya tulasnei Berk. et Br. & 3 & 5 & 29 \\
\hline Choiromyces meandriformis Vittad. & 84 & - & 77 \\
\hline Genea hispidula Berk. et Br. & - & - & 4 \\
\hline Genea fragrans (Wallroth) Paoletti & - & - & 11 \\
\hline Genea klotzschii Berk. \& Broome & 3 & - & 36 \\
\hline Genea lespiaultii Corda & 5 & 1 & 11 \\
\hline Genea sphaerica Tul. & 1 & - & 15 \\
\hline Genea verrucosa Vittad. & 2 & 3 & 115 \\
\hline Genea sp. (undet.) & - & - & 75 \\
\hline Stephensia bombycina (Vittad.) Tul. & 1 & - & 139 \\
\hline Picoa carthusiana Tul. & 2 & - & 3 \\
\hline Hydnobolites cerebriformis Tul. & 3 & 2 & 21 \\
\hline Pachyphloeus spp. & 3 & 13 & 95 \\
\hline Mattirolomyces terfezioides (Matt.) Fisch. & 1 & 7 & 45 \\
\hline Tuber aestivum Vittad. & 51 & 6 & 461 \\
\hline Tuber borchii aggr. (small white truffles) & 20 & 6 & 227 \\
\hline Tuber brumale Vittad. & 1 & 1 & 303 \\
\hline Tuber excavatum aggr. & 22 & 2 & 485 \\
\hline Tuber lucidum Bonn. & - & - & 5 \\
\hline Tuber macrosporum Vittad. & 2 & - & 146 \\
\hline Tuber magnatum Pico & - & - & 50 \\
\hline Tuber mesentericum (Vittad.) Fisch. & 1 & - & 124 \\
\hline Tuber nitidum Vittad. & 5 & - & 10 \\
\hline Tuber regianum Mont. et Lazz. & - & - & 9 \\
\hline Tuber rufum Pico & 19 & 29 & 458 \\
\hline \multicolumn{4}{|l|}{ Zygomycota } \\
\hline Endogone flammicorona Trappe et Gerd. & - & 1 & 9 \\
\hline \multicolumn{4}{|l|}{ Glomeromycota } \\
\hline Glomus caledonium (T.H. Nicolson \& Gerd.) Trappe \& Gerd. & - & 1 & - \\
\hline Glomus fasciculatum (Thaxt.) Gerd. et Trappe & - & 2 & 4 \\
\hline Glomus fulvum (Berk. \& Broome) Trappe \& Gerd. & - & - & 1 \\
\hline Glomus macrocarpum Tul. & - & 6 & 10 \\
\hline Glomus microcarpum Tul. & - & 6 & 6 \\
\hline \multicolumn{4}{|l|}{ Basidiomycota } \\
\hline Leucogaster nudus (Hazsl.) Hollós & 1 & - & 1 \\
\hline Melanogaster ambiguus (Vittad.) Tul. & 15 & 3 & 75 \\
\hline Melanogaster broomeanus Berk apud Tul. & - & - & 41 \\
\hline Melanogaster intermedius Berk. et $\mathrm{Br}$ & - & - & 2 \\
\hline
\end{tabular}


Table 1 - cont.

\begin{tabular}{|l|c|c|c|}
\hline Melanogaster macrosporus Velen. & - & - & 4 \\
\hline Melanogaster tuberiformis Corda & - & - & 2 \\
\hline Melanogaster variegatus (Vittad.) Tul & 22 & 2 & 12 \\
\hline Melanogaster sp. (undet.) & - & - & 49 \\
\hline Rhizopogon roseolus sensu Martín & 15 & 10 & 57 \\
\hline Rhizopogon villosulus Zeller & - & - & 2 \\
\hline Octavianina asterosperma Vittad. & - & - & 38 \\
\hline Phlyctospora fusca Corda & 1 & 3 & 16 \\
\hline Gastroporium simplex Matt. & - & 2 & 7 \\
\hline Hypogeic Russulales & 2 & 1 & 36 \\
\hline Gautieria spp. & 13 & 1 & 56 \\
\hline Hysterangium calcareum Hesse & - & - & 2 \\
\hline Hysterangium clathroides Vittad. & 21 & - & 2 \\
\hline Hysterangium coriaceum Hesse & - & - & 3 \\
\hline Hysterangium crassum (Tul. \& C. Tul.) E. Fisch. & - & - & 27 \\
\hline Hysterangium membranaceum Vittad. & 2 & - & - \\
\hline Hysterangium nephriticum Berk. & - & - & 2 \\
\hline Hysterangium pompholyx Tul. & 1 & - & 1 \\
\hline Hysterangium stoloniferum Tul. & 11 & 2 & 29 \\
\hline Hymenogaster tener Berk. & 3 & 4 & 3 \\
\hline Hymenogaster arenarius Tul. & 2 & 7 & 8 \\
\hline Hymenogaster bulliardii Vittad. & - & - & 35 \\
\hline Hymenogaster citrinus Vittad. & - & 2 & 62 \\
\hline Hymenogaster griseus Vittad. & 10 & 11 & 99 \\
\hline Hymenogaster hessei Soeehner & - & - & 28 \\
\hline Hymenogaster luteus Vittad. & - & 1 & 103 \\
\hline Hymenogaster niveus Vittad. & - & - & 41 \\
\hline Hymenogaster rehsteineri Bucholtz & - & - & 23 \\
\hline Wakefieldia macrospora Hawker & - & - & 2 \\
\hline Sclerogaster spp. & - & - & 14 \\
\hline
\end{tabular}

(Corda) T. M. Fr. (Martín, 1996). Species new to the list due to rearrangements are: Glomus macrocarpum Tul. and Glomus microcarpum Tul.

The revision of Hymenogaster species by the complex evaluation of molecular and morphological data, and using samples from the Carpathian-Pannonian region revealed that Hymenogaster griseus Vittad. 1831 (emend Stielow et al. 2010) includes the species H. lilacinus Tul. (probably), H. lycoperdineus Vittad., H. muticus Berk. et Br. (probably), H. populetorum Tul. and $H$. vulgaris Tul., while Hymenogaster citrinus Vittad. includes the species $H$. olivaceus Vittad.

Preliminary molecular biology studies have indicated that revision of the traditional species boundaries is needed in some genera. The following genera are being revised on molecular taxonomical basis: Arcangeliella-Zelleromyces, Gautieria, Genea, Glomus, Hysterangium, Melanogaster, Pachyphloeus and Sclerogaster. In other genera only certain species groups need to be revised by means of molecular taxonomy, such as Elaphomyces muricatus/decipiens/reticulatus/asperulus, Hymenogaster niveus aggr., Hymenogaster rehsteineri aggr., Tuber rufum aggr., Tuber excavatum aggr. and Tuber borchii aggr.

New species, extinct species and very rare species. Bratek et al. (1999) described sixteen species new to the Carpathian-Pannonian region including Elaphomyces persoonii Vittad., Endogone flammicorona Trappe et Gerd., Hysterangium pompholyx Tul., Sclerogaster compactus (Tul.) Sacc., Tuber magnatum Pico, Tuber regianum Mont. et Lazz. and Wakefieldia macrospora Hawker. But for T. magnatum and 
Endogone flammicorona, which is often found in acidic conifer woodlands, all the above species are still regarded as very rare. T. magnatum has been collected in great quantities from the gallery forests of the southern Pannonicum in the past few years. In a habitat rich in T. magnatum today, Hollós used to collect other species. Moreover, Szemere collected plenty of hypogeous fungi in this county, too. All these facts may confirm the assumption that the distribution boundary of T. magnatum is shifting northwards as climate becomes warmer (Bratek 2008). However, its advance is limited as the majority of riverine oak-elm-ash woodlands were cut and disappeared in the last century.

During the above mentioned revision of Hymenogaster, two species new to the region: $H$. megasporus Soehner and $H$. pruinatus Hesse, and two species new to science: H. intermedius Stielow et al. 2010 and H. huthii Stielow et al. 2010 were also found (Stielow et al. 2011).

Stielow et al (2010) came across Hydnotria michaelis (Fischer) Trappe, a species new to the region in Sklene, Slovakia. Glejdura (2011) recorded Stephanospora caroticolor, also new to the region in the Lesser Fatra (Malá Fatra), part of the northwestern Carpathians. Montecchi et Sarasini (2000) reported on Pachyphloeus prieguensis Moreno-Arroyo, Gomez and Calonge, also new to the region, in the vicinity of Budapest. Similarly, specimens of the species Rhizopogon villosus Zeller turned up in an arboretum near Budapest (Bratek 2006), which had probably got there together with plant specimens from America.

The Red List compiled by Rimóczi et al. (1999), which assigns nature conservation values to macrofungi, contains most of the hypogeous fungi in Hungary. According to this Red List Leucogaster nudus is critically endangered, while Gastrosporium simplex and Picoa carthusiana are endangered. Our latest data confirm the validity of this categorization. Of the native hypogeous fungi only six black-peridium Elaphomyces species have so far received protection owing to their rarity (Siller et al. 2005). E. pyriformis Vittad. with also black peridium has not been found since Hollós (1911) and is supposed to have vanished from the funga of the region.

Species with highly changed frequency of occurrence. Table 1 contains a number of species whose frequency of collection has increased significantly or even by orders of magnitude. Based on their pronounced, strong odour, it is fair to assume that the widespread of collecting with dogs is responsible for an increase in their frequency of collection. Hence, we propose naming these species truffle dog preferred hypogeous fungi (DPH).

The number of fungarium data increased mostly for T. brumale, whose excellent odour places it among DPH species. Molecular studies have revealed genetic heterogeneity in the winter truffles of the region, confirming the hypothesis that $T$. brumale is not an invasive species in this biogeographical region, but has long been part of the hypogeous funga (Merényi et al. 2012). The same stands for Tuber mesentericum, whose genetic diversity has also been proved in the region (Sica et al. 2007). Tuber macrosporum also belongs here, as its rich localities have given the species commercial importance. We consider Tuber aestivum a DPH, too, since the number of its known localities has increased by more than one order of magnitude. The great majority of marketed T. aestivum originate from the high productivity woodlands of the Jászság region, thus making Hungary the most significant exporter of the species. 
As of 2013, trufflers are obliged to keep records of the quantity of collected truffles in their collection notebook according to Hungarian legal regulations, which enables forestry authorities to follow any changes in the amount of collected T. aestivum. An opposing trend, a significant drop of records occurs for Choiromyces meandriformis. Earlier, the species was common in local market places (Hollós 1911), but has become rather unpopular in the European cuisine. At the same time, Mattirolomyces terfezioides has the potential to become a rising star in truffle gastronomy thanks to its prominent sweet taste. Besides a few records in other regions (Kovács 2009), its richest habitats are found in the Pannonicum, in black locust plantations growing on sand deposited by the Danube (Gógán et al. 2008).

Stephensia bombycina and Octaviania asterosperma are also DPH species that were classified as endangered due to the scarcity of data (Rimóczi et al. 1999), but are not considered as rare anymore.

In the above three chapters of the Discussion, we presented species whose frequency of occurrence could be estimated from collection data. However, the unearthing of the hypogeous fungi of the Carpathian-Pannonian region is far from being finished, as some regions/landscapes have only slightly or not at all been studied. Moreover, the mapping of surveyed species did not follow the most adequate method in all cases. The frequency estimation of DPH species appears to be the most reliable/straightforward. The adequacy of mapping methodology has outstanding importance in the case of other species. A further obstacle to the evaluation of hypogeous funga is the uncertainty of species boundaries in several genera, where intensive molecular taxonomic work is needed or is in progress. The relevance of such research lies in the fact that ecological studies and conservation assessments can only operate with stable species concepts. All the above results have the potential to further clarify and harmonize our understanding of the funga of the Carpathian-Pannonian region and its changes.

Acknowledgements. This research has been supported by the MIKOQUAL project under the Ányos Jedlik Programme and by the QUTAOMEL project under the National Technology Programme. We wish to thanks the reviewers for their valuable remarks and advice.

\section{REFERENCES}

Bratek Z., Albert L.I., Bagi B., Pálfy T., Takács Sz., Rudnóy K., Halász K. 1999. New and rare hypogeous fungi of Carpathian basin. Actes du Ve Congrès International, Science et Culture de la Truffe et des autres Champignons Hypoges Comestibles. 4-6 mars 1999, Aix-en-Provence, Federation Française des Trufficulteurs: 255-256, France.

Bratek Z., Halász K. 2001. A Kárpát-medence földalatti gombái. (In:) II. Kárpát-medencei Biológiai Szimpózium. Magyar Biológiai Társaság \& Magyar Természettudományi Múzeum. November 2022, 2001. Előadások Összefoglalói, Budapest: 51-55.

Bratek Z. 2005. Szemere László: Föld alatti gombavilág. Első Magyar Szarvasgombász Egyesület, Budapest.

Bratek Z., Halász K. 2005. Kiegészítések a második kiadáshoz. (In:) Szemere László: Föld alatti gombavilág. Első Magyar Szarvasgombász Egyesület, Budapest: 176-180.

Bratek Z. 2006. Biodiversity of hypogeous fungi in Carpathian region. Biodiversity of hypogeous fungi 1: 11-14. 
Bratek Z. 2008. Les effets du changement climatique sur les champignons hypogés et sur le genre Tuber en Hongrie. (In:) Y. Rousset-Rouard (ed.). Lavenir de la truffe face au réchauffement climatique. Éditions Albin Michel. Ménerbes: 109-110.

Glejdura S. 2011. Stephanospora caroticolor in Slovakia. Catathelasma 13: 29-32.

Gógán A. Cs., Bratek Z., Merényi Zs., Illyés Z., Dimény J. 2008. Choiromyces meandriformis and Mattirolomyces terfezioides: peculiar truffles with new perspectives, Micologia Italiana: 26-32.

Halász K., Bratek Z., Szegő D., Rudnóy Sz., Rácz I., Lásztity D., Trappe J. 2005. Tests of species concepts on the small, white European group of Tuber spp. based on morphology and rDNA ITS sequences with special reference to Tuber rapaeodorum. Mycological Progress 4 (4): 281-290.

Hollós L. 1911. Magyarország földalatti gombái, szarvasgombaféléi. (Fungi hypogaei Hungariae.). K.M. Természettudományi Társulat, Budapest.

Kovács G.M., Martín M.P., Calonge F.D. 2009. First record of Mattirolomyces terfezioides from the Iberian Peninsula: its southern- and westernmost locality. Mycotaxon 110: 235-330.

Ławrynowicz M. 1989. Chorology of the European hypogeous Ascomycetes I. Elaphomycetales. Acta Mycol. 25 (1): 3-41.

Ławrynowicz M. 1990. Chorology of the European hypogeous Ascomycetes. II. Tuberales.Acta Mycol. 26: 7-75.

Ławrynowicz M. 1992. Distributional Limits of Truffles in the Northern Europe. Micologia e Vegetazione Mediterranea 7 (1): 31-38.

Martín M.P. 1996. The genus Rhizopogon in Europe. Specials Societat Catalana Micologia: 1-173.

Merényi Zs., Illyés Z., Völcz G., Bratek Z. 2010. Creation database application for development on truffle cultivation methods. Austrian Journal of Mycology 19: 239-244.

Merényi Zs., Varga T., Geml J., Chevalier G., Bratek Z. 2012. A Tuber brumale aggr. filogenetikai elemzése (Phylogenetic analysis of Tuber brumale aggr.) V. Magyar Mikológiai Konferencia. Budapest 2012. Mikológiai Közlemények, Clusiana 51 (1): 18-20.

Montecchi A., Sarasini M. 2000. Funghi ipogei d'Europa. Associazione Micologica Bresadola, Centro Studi Micologici, Vicenza.

Rimóczi I., Siller I., Vasas G., Albert L., Vetter J., Bratek Z. 1999. Magyarország nagygombáinak javasolt vörös listája. Mikológiai Közlemények 38 (1/3): 107-132.

Riousset L., Chevalier G., Bardet M.C. 2001. Truffes d'Europe et de Chine. INRA, Paris 2001.

Sica M., Gaudio L., Aceto S. 2007. Genetic structure of Tubermesentericum Vitt. based on polymorphisms at the ribosomal DNAITS. Mycorrhiza 17 (5): 405-414. http://dx.doi.org/10.1007\%2Fs00572-007-0115-8

Siller I., Vasas G., Pál-Fám F., Bratek Z., Zagyva I., Fodor L. 2005. Hungarian distribution of the legally protected macrofungi species. Studia bot. hung 36: 131-163.

Stanners D., Bourdeau, P. (eds). 1995. Europe's environment: the Dobris Assessment. - Copenhagen: European Environment Agency. ISBN 92-827-4713-1

Stielow B., Bubnek B., Hensel G., Münzenberger B., Hoffmann P., Klenk H.-P., Göker M. 2010. "The neglected hypogeous fungus Hydnotrya bailii Soehner (1959) is a widespread sister taxon of Hydnotrya tulasnei (Berk.) Berk. \& Broome (1846)”. Mycological Progress 9 (2): 195-203.

Stielow B., Bratek Z, Orczán A.K., Rudnóy Sz., Hensel G. 2011. Species Delimitation in Taxonomically Difficult Fungi: The Case of Hymenogaster. PLoS ONE 6 (1): e15614.

Szemere L. 1965. Die unterirdischen Pilze des Karpatenbeckens. Akadémiai Kiadó, Budapest.

Szemere L. 1970. Föld alatti gombavilág (The world of undeground fungi). Mezőgazdasági Kiadó, Budapest.

Trappe J.M. 1969. Comments on Szemere's „Die unterirdischen Pilze des Karpatenbeckens”. Mycologia 61: 170-174. http://dx.doi.org/10.2307\%2F3757355 